\title{
Evidence for a paracrine role of endogenous adrenomedullary galanin in the regulation of glucocorticoid secretion in the rat adrenal gland
}

\author{
PAOLA G. ANDREIS ${ }^{1}$, CINZIA TORTORELLA ${ }^{1}$, AGNIESKA ZIOLKOWSKA ${ }^{2}$, RAFFAELLA SPINAZZI ${ }^{1}$, \\ LUDWIK K. MALENDOWICZ ${ }^{2}$, GIULIANO NERI ${ }^{1}$ and GASTONE G. NUSSDORFER ${ }^{1}$ \\ ${ }^{1}$ Department of Human Anatomy and Physiology, Section of Anatomy, University of Padua, I-35121 Padua, Italy; \\ ${ }^{2}$ Department of Histology and Embryology, Poznan School of Medicine, PL-60781 Poznan, Poland
}

Received October 13, 2006; Accepted November 24, 2006

\begin{abstract}
Previous investigations have shown that rat adrenocortical cells are provided with galanin receptors, and galanin stimulates glucocorticoid secretion from dispersed cells. The present study aimed to clarify the possible role of galanin in the physiological regulation of rat adrenal secretory activity. Reverse transcription-polymerase chain reaction detected galanin mRNA expression in the adrenal medulla, but not in the cortex. Sizeable concentrations of galanin-immunoreactivity were measured by radioimmune assay only in the adrenomedullary tissue. Galanin raised norepinephrine, but not epinephrine, release from adrenomedullary tissue. Galanin immunoneutralization (obtained with concentrations of anti-galanin antibody able to block the galanin glucocorticoid secretagogue effect on dispersed adrenocortical cells) decreased basal corticosterone production from adrenal slices containing adrenomedullary tissue, without affecting that from dispersed adrenocortical cells. The $\beta$-adrenoceptor antagonist $l$-alprenolol partially prevented galanin-stimulated corticosterone secretion from adrenal slices, without per se altering basal secretion. Taken together, our findings allow us to conclude that endogenous galanin, produced in adrenal medulla, is involved in the regulation of adrenocortical glucocorticoid secretion acting via a two-fold paracrine mechanism: i) direct activation of adrenocortical galanin receptors; and ii) stimulation of adrenomedullary release of catecholamines, which in turn activate $\beta$-adrenoceptors located on adrenocortical cells.
\end{abstract}

Correspondence to: Professor G.G. Nussdorfer, Department of Human Anatomy and Physiology, Section of Anatomy, University of Padua, Via Gabelli 65, I-35121 Padua, Italy

E-mail: gastone.nusdorfer@unipd

Key words: galanin, adrenal cortex, adrenal medulla, catecholamine secretion, corticosterone secretion, rat

\section{Introduction}

Galanin is a regulatory peptide, which is widely distributed in the central and peripheral nervous system, where it acts as a neuromodulator (reviewed in ref. 1). Recent findings showed that galanin enhances glucocorticoid (corticosterone), but not mineralocorticoid (aldosterone) secretion from dispersed rat inner adrenocortical cells, acting via GAL-R1 and GAL-R2 receptors coupled to the adenylate cyclase-dependent signaling cascade (2).

Evidence indicates that adrenomedullary cells express the galanin gene (3-5), and radioimmune assay (RIA)-measurable galanin immunoreactivity (IR) was detected in fresh rat adrenal medulla $(6,7)$. These observations could suggest a role for galanin in the regulation of adrenomedullary functions, but in vitro investigations on the effect of this peptide on catecholamine secretion are lacking.

Therefore, it seemed worthwhile to examine in vitro the effects of galanin on catecholamine secretion, and to ascertain whether, as in the case of other regulatory peptides contained in medullary chromaffin cells (reviewed in ref. 8), the possible interactions of galanin with adrenomedullary cells may concur to the secretagogue action of this peptide on the adrenal cortex.

\section{Materials and methods}

Animals and reagents. Male Sprague-Dawley rats (200-250 g body weight) were provided by Charles-River (Como, Italy). Rats were decapitated, and their adrenals were promptly removed and cleaned of adherent fat. The protocol of the experiment was approved by the local Ethics Committee for Biomedical Studies. Rat galanin and anti-rat galanin antibody were purchased from Phoenix Pharmaceuticals (Belmont, CA). Medium 199 was obtained from Difco (Detroit, MI). Human serum albumin (HSA), $l$-alprenolol, and all other chemicals and laboratory reagents were provided by SigmaAldrich Corporation (St. Louis, MO).

Reverse transcription ( $R T)$-polymerase chain reaction $(P C R)$. Total RNA was extracted from the frozen adrenal cortex and medulla, and reverse transcribed to cDNA (9-11). 
PCR was performed in a Delfi 100 thermal cycler (MT Research Inc., Waterstone, MA), as previously detailed (12-14). As positive control, the expression of the housekeeping gene glyceraldehyde-3-phosphate dehydrogenase (GAPDH) was detected, and to rule out the possibility of amplifying genomic DNA, one PCR was carried out without prior RT of the RNA. Detection of the PCR amplification products was performed by size fractionation on $2 \%$ agarose-gel electrophoresis. The specificity of the PCR was verified by sequencing analysis (15). Primer sequence, predicted size of amplicons, and PCR program are indicated in the legend of Fig. 1.

Galanin-RIA. Fresh preweighed adrenal cortex and medulla samples were extracted, as previously detailed (16). Galanin concentration was measured, using the rat-galanin RIA kit of Phoenix Pharmaceuticals; sensitivity, $210 \mathrm{pg} / \mathrm{ml}$; crossreactivity, rat galanin, $100 \%$ and other peptides, $0 \%$; and intraassay and interassay CVs: $7 \%$ and 9\%, respectively.

Preparation of adrenal specimens. Adrenals were decapsulated to eliminate zona glomerulosa, and then halved and enucleated to separate adrenal medulla from inner zona fasciculata-reticularis. Dispersed inner adrenocortical cells were obtained by sequential collagenase digestion and mechanical disaggregation (17). Other adrenals were sliced, and slices containing both cortical and medullary tissues (4-6 mg of tissue) were selected. Adrenomedullary tissue, dispersed cells and adrenal slices were placed (105 cells or 4-6 mg tissue/ml) in Medium 199 and Krebs-Ringer bicarbonate buffer with $0.2 \%$ glucose and $5 \mathrm{mg} / \mathrm{ml} \mathrm{HSA}$, and incubated as described below.

Experimental design. Dispersed inner adrenocortical cells were incubated as follows: i) galanin $\left(10^{-8} \mathrm{M}\right)$ in the presence of increasing concentrations of anti-galanin antibody (1-6 $\mu \mathrm{g} /$ $\mathrm{ml}$ ); and ii) anti-galanin antibody (4 or $6 \mu \mathrm{g} / \mathrm{ml}$ ). Adrenomedullary tissue was incubated with increasing concentrations of galanin $\left(10^{-12}-10^{-6} \mathrm{M}\right)$. Adrenal slices were incubated as follows: i) anti-galanin antibody (4 or $6 \mu \mathrm{g} / \mathrm{ml}$ ); and ii) antigalanin antibody $(6 \mu \mathrm{g} / \mathrm{ml})$ and/or $l$-alprenolol $\left(10^{-5} \mathrm{M}\right)$ in the presence or absence of galanin $\left(10^{-6} \mathrm{M}\right)$. Incubation was carried out for $60 \mathrm{~min}$ (steroid hormone production) or $30 \mathrm{~min}$ (catecholamine production) in a shaking bath at $37^{\circ} \mathrm{C}$ in an atmosphere of $95 \%$ air- $5 \% \mathrm{CO}_{2}$. At the end of the experiments, the incubation tubes were centrifuged at $4{ }^{\circ} \mathrm{C}$, and media were collected and stored at $-80^{\circ} \mathrm{C}$.

Hormone assay. Corticosterone was extracted from incubation media and purified by high pressure liquid chromatography (HPLC) (18), and its concentration was measured by RIA, as previously described $(19,20)$; sensitivity, $50 \mathrm{pg} / \mathrm{ml}$; and intraassay and interassay CVs, 7.2 and $8.5 \%$, respectively. Epinephrine (E) and nor-epinephrine (NE) concentrations were measured by HPLC, using a reverse phase column and glassy carbon electrochemical detector $(21,22)$; sensitivity, $3 \mathrm{fmol} / \mathrm{ml}$; and intraassay and interassay CVs, 6.4 and $7.9 \%$, respectively.

Statistics. Data were expressed as means \pm SD or SEM of the number of independent experiments indicated in the figure

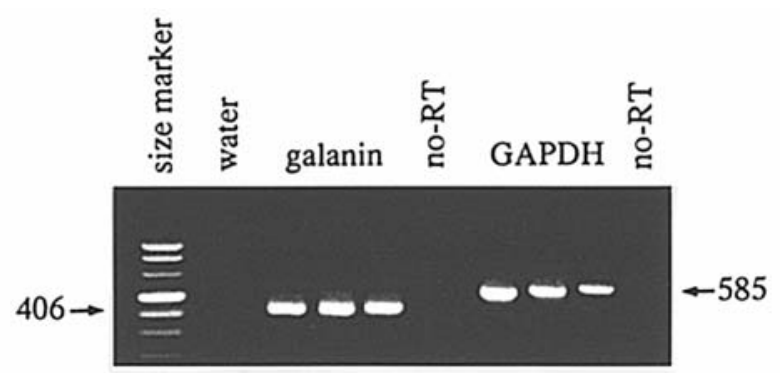

Figure 1. Ethidium bromide-stained $2 \%$ agarose gel showing cDNA amplified with rat galanin specific primers from RNA of adrenal medulla of three exemplary rats. Primer sequences were: galanin sense-128-5', 5'-CCC ACCACTGCTCAAGAT-3' and antisense-534-3', 5'-GCAGAGGACACA GGTGCA-3' (amplicon, 406 bp); and GAPDH sense-181-5', 5'-CCCTTCA TTGACCTCAACTA-3' and antisense-765-3', 5'-GCCAGTGAGCTTCC CGTTCA-3' (amplicon, $585 \mathrm{bp}$ ). The PCR program was 35 cycles at $94^{\circ} \mathrm{C}$ for $30 \mathrm{sec}, 57^{\circ} \mathrm{C}$ for $30 \mathrm{sec}$ and $72^{\circ} \mathrm{C}$ for $30 \mathrm{sec}$, followed by a final extension step at $72^{\circ} \mathrm{C}$ for $5 \mathrm{~min}$. Lane 1 was loaded with $200 \mathrm{ng}$ of a size marker (Marker VIII; Roche, Mannheim, Germany). No amplification with water instead of RNA or without prior RT of RNA (no RT) are shown as negative controls.

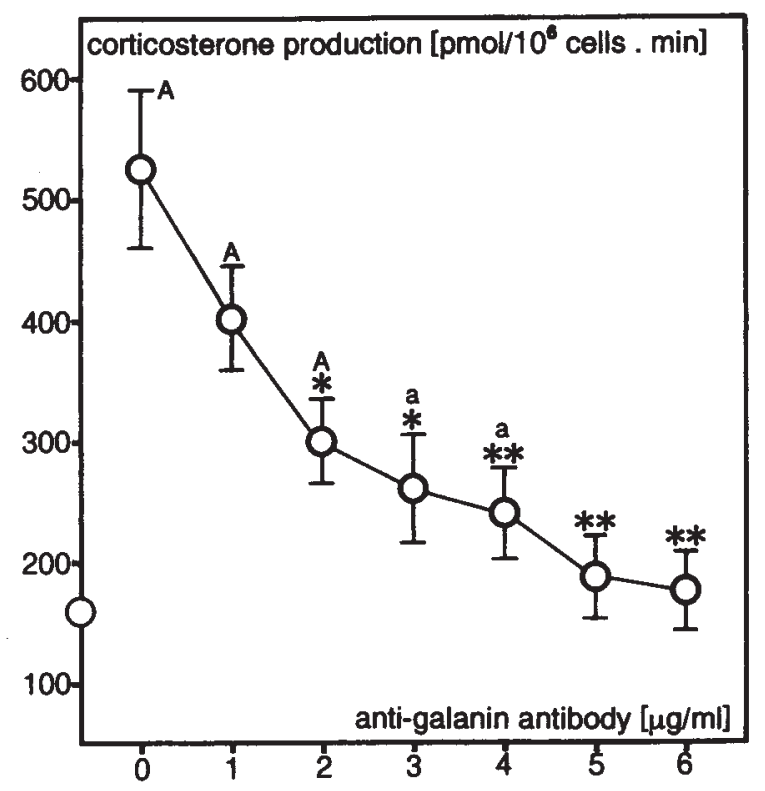

Figure 2. Effect of galanin immunoneutralization on galanin $\left(10^{-8} \mathrm{M}\right)$ stimulated corticosterone production from dispersed rat inner adrenocortical cells. Basal corticosterone secretion is shown on the ordinate. Each point represents the mean $\pm \mathrm{SD}$ of three separate experiments. ${ }^{*} \mathrm{P}<0.05$ and ${ }^{* *} \mathrm{P}<0.01$ from control value (no anti-galanin antibody); ${ }^{\mathrm{a}} \mathrm{P}<0.05$ and ${ }^{\mathrm{A}} \mathrm{P}<0.01$ from baseline value.

legends. Statistical analysis was carried out by ANOVA, followed by Duncan's multiple range test.

\section{Results}

RT-PCR detected the expression of galanin mRNA in the rat adrenal medulla (Fig. 1), but not adrenal cortex (data not shown). RIA measured sizeable concentrations of galanin-IR in the rat adrenal medulla $(82.7 \pm 23.2 \mathrm{SD} \mathrm{pmol} / \mathrm{g}$; $\mathrm{n}=10)$; in the adrenal cortex the concentrations of the peptide were below the limit of sensitivity of our assay. 


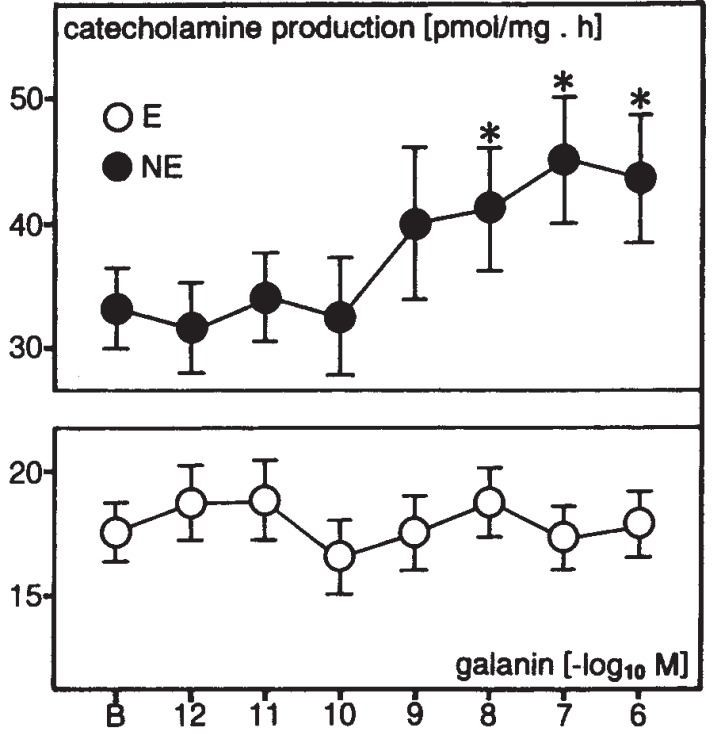

Figure 3. Effect of galanin on catecholamine secretion from adrenomedullary slices. Each point represents the mean \pm SEM of six separate experiments. ${ }^{*} \mathrm{P}<0.05$ from baseline $(\mathrm{B})$ value.

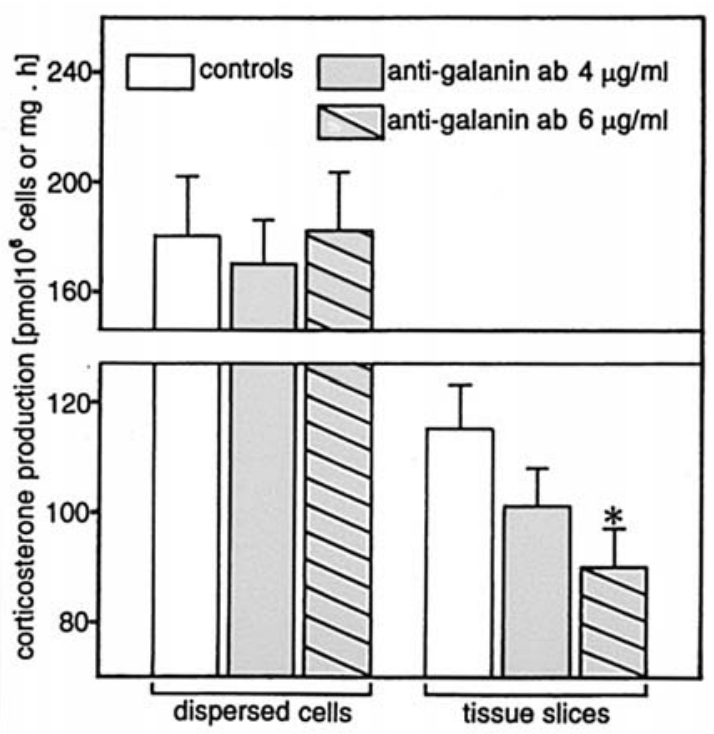

Figure 4. Effect of galanin immunoneutralization on basal corticosterone production from dispersed rat inner adrenocortical cells and adrenal slices containing medullary tissue. Bars are the mean \pm SEM of eight separate experiments. ${ }^{*} \mathrm{P}<0.05$ from the respective control value.

Similar to our previous study (2), galanin $\left(10^{-8} \mathrm{M}\right)$ enhanced $\sim 3$-fold the corticosterone secretion from dispersed rat inner adrenocortical cells. Corticosterone response to galanin was inhibited by anti-galanin antibody exposure in a concentration-dependent manner, a complete blockade being obtained with an antibody concentration of $5-6 \mu \mathrm{g} / \mathrm{ml}$ (Fig. 2).

Galanin, at concentrations ranging from $10^{-8}-10^{-6} \mathrm{M}$, raised $\mathrm{NE}$ secretion from rat adrenomedullary tissue (from 20 to $30 \%$ ), while E production was not affected (Fig. 3). The exposure to the maximal effective concentration of antigalanin antibody did not alter either basal NE secretion from

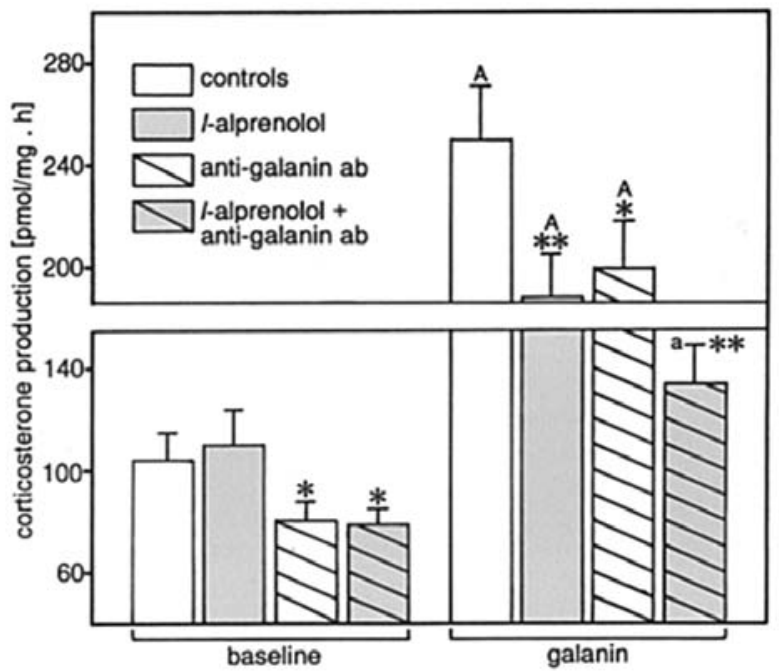

Figure 5. Effects of $l$-alprenolol and/or galanin immunoneutralization on basal and galanin-stimulated corticosterone production from adrenal slices containing medullary tissue. Bars are the mean \pm SEM of eight separate experiments. ${ }^{*} \mathrm{P}<0.05$ and ${ }^{* *} \mathrm{P}<0.01$ from the respective control value; ${ }^{\mathrm{P}}<0.05$ and ${ }^{\mathrm{A}} \mathrm{P}<0.01$ from the respective baseline value.

adrenomedullary tissue (data not shown) or basal corticosterone secretion from dispersed inner adrenocortical cells (Fig. 4). However, it evoked a significant lowering of corticosterone secretion from adrenal slices (-22\%) (Fig. 4). Antigalanin antibody lowered both basal- and galanin $\left(10^{-6} \mathrm{M}\right)$ stimulated corticosterone secretion from adrenal slices, while l-alprenolol $\left(10^{-5} \mathrm{M}\right)$ decreased only galanin-stimulated production (Fig. 5).

\section{Discussion}

Our present findings clearly show that galanin is expressed in the rat adrenal medulla as mRNA and protein. RIA detected galanin concentrations $>80 \mathrm{pmol} / \mathrm{g}$, which, as previously calculated (8), can give rise to local intra-adrenal levels of the peptide of $\sim 10^{-7} / 10^{-6} \mathrm{M}$. This finding, along with the demonstration of the presence of galanin receptors in adrenocortical and adrenomedullary cells (2) and the fact that in the rat the blood level of galanin does not exceed $10^{-10} \mathrm{M}$ (23), strongly suggest that galanin may modulate adrenocortical function in a paracrine manner. Our present study gives support to this contention, and also indicates that the endogenous galanin/galanin receptor system plays a relevant role in the physiological regulation of adrenocortical secretion.

This contention is based on the evidence that the exposure of adrenocortical slices, containing adrenal medulla and hence sizeable levels of endogenous galanin, to anti-galanin antibodies lowers basal secretion of corticosterone. The antibodies are able to block the galanin-stimulated corticosterone secretion from dispersed rat zona fasciculata-reticularis cells, but not their basal corticosterone secretion, which accords well with the lack of endogenous galanin in rat adrenocortical tissue.

Many lines of evidence indicate that several adrenomedullary peptides are able to regulate adrenocortical function through a two-fold paracrine mechanism (reviewed in ref. 8). 
They may directly activate their receptors located on adrenocortical cells or may elicit the release from medullary chromaffin cells of catecholamines, which in turn stimulate secretion of adrenocortical cells via $\beta$-adrenoceptors located on them. This latter mechanism has been documented for VIP and PACAP, neuropeptide-Y, tackykinins, endothelins, adrenomedullin (reviewed in refs. 24-28), cerebellin $(29,30)$, and ANP (31).

The following pieces of evidence allow us to include galanin in this group of regulatory peptides: i) galanin enhances NE release from rat medullary cells; ii) the $\beta$ adrenoceptor antagonist $l$-alprenolol (8) partially prevents galanin-stimulated corticosterone secretion from adrenal slices; and iii) $l$-alprenolol per se does not alter basal corticosterone production from adrenal slices, thereby ruling out the possibility that the effect of this antagonist was due to a nonspecific toxic effect on the steroidogenic pathways of adrenocortical cells. This last observation makes it unlikely that catecholamine release may be involved in the regulatory effect of endogenous galanin on corticosterone secretion under basal conditions, and this contention agrees with the lack of effect of the exposure to anti-galanin antibodies on the basal catecholamine secretion from adrenomedullary tissue. Hence, it seems reasonable to hypothesize that only paraphysiological or pathological conditions able to elicit massive galanin release within adrenal medulla may allow this peptide to reach local concentrations sufficient to evoke catecholamine secretion.

In conclusion, our study provides evidence suggesting that endogenous galanin may be involved in the paracrine control of glucocorticoid secretion from rat adrenal cortex, and investigations are underway to ascertain which are the possible stimuli able to modulate galanin release from medullary chromaffin cells.

\section{References}

1. Bedecs K, Berthold M and Bartfai T: Galanin. 10 Years with a neuroendocrine peptide. Int J Biochem Cell Biol 27: 337-349, 1995.

2. Andreis PG, Malendowicz LK, Rebuffat P, Spinazzi R, Ziolkowska A and Nussdorfer GG: Galanin enhances corticosterone secretion from dispersed rat adrenocortical cells through the activation of GAL-R 1 and GAL- $\mathrm{R}_{2}$ receptors coupled to the adenylate cyclase-dependent signaling cascade. Int J Mol Med 19: 149-155, 2007.

3. Zentel HJ, Nohr D, Müller S, Yanaihara N and Weihe E: Differential occurrence and distribution of galanin in adrenal nerve fibres and medullary cells in rodents and avian species. Neurosci Lett 120: 167-170, 1990.

4. Dagerlind A, Pelto-Huikko M, Lundberg JM, Ubink R, Verhofstad A, Brimijoin S and Hökfelt T: Immunologically induced sympathectomy of preganglionic nerves by antibodies against acetylcholinesterase: increased levels of peptides and their messenger RNAs in rat adrenal chromaffin cells. Neuroscience 62: 217-239, 1994.

5. Anouar Y and Eiden LE: Rapid and long-lasting increase in galanin mRNA levels in rat adrenal medulla following insulininduced reflex splanchnic nerve stimulation. Neuroendocrinology 62: 611-618, 1995.

6. Fischer-Colbrie R, Eskay RL, Eiden LE and Maas D: Transsynaptic regulation of galanin, neurotensin, and substance $\mathrm{P}$ in the adrenal medulla: combinatorial control by second-messenger signaling pathways. J Neurochem 59: 780-783, 1992.

7. Holgert H, Dagerlind A, Hökfelt T and Lagercrantz H: Neuronal markers, peptides and enzymes in nerves and chromaffin cells in the rat adrenal medulla during postnatal development. Dev Brain Res 83: 35-52, 1994.
8. Nussdorfer GG: Paracrine control of adrenal cortical function by medullary chromaffin cells. Pharmacol Rev 48: 495-530, 1996.

9. Albertin G, Carraro G and Nussdorfer GG: Human adrenomedullin gene silencing by short interfering RNAs: A preliminary study. Int J Mol Med 15: 579-583, 2005.

10. Andreis PG, Rucinski M, Neri G, Conconi MT, Petrelli L, Parnigotto PP, Malendowicz LK and Nussdorfer GG: Neuropeptides $\mathrm{B}$ and $\mathrm{W}$ enhance the growth of human adrenocortical carcinoma-derived NCI-H295 cells by exerting MAPK p42/p44-mediated proliferogenic and antiapoptotic effects. Int J Mol Med 16: 1021-1028, 2005.

11. Rucinski M, Andreis PG, Ziolkowska A, Nussdorfer GG and Malendowicz LK: Differential expression and function of beacon in the rat adrenal cortex and medulla. Int J Mol Med 16: 35-40, 2005.

12. Albertin G, Carraro G, Petrelli L, Guidolin D, Neri G and Nussdorfer GG: Endothelin-1 and adrenomedullin enhance the growth of human adrenocortical carcinoma-derived SW-13 cell line by stimulating proliferation and inhibiting apoptosis. Int $\mathrm{J}$ Mol Med 15: 469-474, 2005.

13. Albertin G, Rucinski M, Carraro G, Forneris M, Andreis PG, Malendowicz LK and Nussdorfer GG: Adrenomedullin and vascular endothelium growth factor genes are overexpressed in the regenerating rat adrenal cortex, and AM and VEGF reciprocally enhance their mRNA expression in cultured rat adrenocortical cells. Int J Mol Med 16: 431-435, 2005.

14. Rucinski M, Albertin G, Spinazzi R, Ziolkowska A, Nussdorfer GG and Malendowicz LK: Cerebellin in the rat adrenal gland: gene expression and effects of CER and [des-Ser ${ }^{1}$ CEER on the secretion and growth of cultured adrenocortical cells. Int J Mol Med 15: 411-415, 2005.

15. Rossi GP, Sticchi D, Giuliani L, Bernante P, Zavattiero S, Pessina AC and Nussdorfer GG: Adiponectin receptor expression in the human adrenal cortex and aldosteroneproducing adenomas. Int J Mol Med 17: 975-980, 2006.

16. Bauer FE, Hacker GW, Terenghi G, Adrian TE, Polak JM and Bloom SR: Localization and molecular forms of galanin in human adrenals: elevated levels in pheochromocytomas. J Clin Endocrinol Metab 63: 1372-1378, 1986.

17. Belloni AS, Rossi GP, Andreis PG, Neri G, Albertin G, Pessina AC and Nussdorfer GG: Endothelin adrenocortical secretagogue effect is mediated by the $\mathrm{B}$ receptor in rats. Hypertension 27: 1153-1159, 1996.

18. Neri G, Malendowicz LK, Andreis PG and Nussdorfer GG: Thyrotropin-releasing hormone inhibits glucocorticoid secretion of rat adrenal cortex: in vivo and in vitro studies. Endocrinology 133: 511-514, 1993

19. Hochol A, Albertin G, Nussdorfer GG, Spinazzi R, Ziolkowska A, Rucinski M and Malendowicz LK: Effects of neuropeptides B and $\mathrm{W}$ on the secretion and growth of rat adrenocortical cells. Int J Mol Med 14: 843-847, 2004.

20. Spinazzi R, Petrelli L, Guidolin D, Carraro G, Casale V, Tortorella C, Neri G, Albertin G, Andreis PG and Nussdorfer GG: In vitro culture on Matrigel favors the long-term maintenance of rat zona glomerulosa-cell differentiated phenotype. Int J Mol Med 17: 1101-1110, 2006.

21. Neri G, Andreis PG, Prayer-Galetti T, Rossi GP, Malendowicz LK and Nussdorfer GG: Pituitary adenylate cyclase-activating peptide (PACAP) enhances aldosterone secretion of human adrenal gland: evidence for an indirect mechanism probably involving the local release of catecholamines. J Clin Endocrinol Metab 81: 169-173, 1996.

22. Ziolkowska A, Rucinski M, Neri G, Di Liddo R, Nussdorfer GG and Malendowicz LK: Expression of the beacon gene in the rat adrenal gland: Direct inhibitory effect of beacon[47-73] an aldosterone secretion from dispersed adrenal zona glomerulosa cells. Int J Mol Med 13: 215-219, 2004.

23. Vrontakis ME, Schroedter IC, Cosby H and Friesen HG: Expression and secretion of galanin during pregnancy in the rat. Endocrinology 130: 458-464, 1992.

24. Nussdorfer GG and Malendowicz LK: Role of tachykinins in the regulation of the hypothalamo-pituitary-adrenal axis. Peptides 19: 949-968, 1998.

25. Nussdorfer GG, Rossi GP, Malendowicz LK and Mazzocchi G: Autocrine-paracrine endothelin system in the physiology and pathology of steroid secreting tissues. Pharmacol Rev 51: 403-438, 1999.

26. Nussdorfer GG: Proadrenomedullin-derived peptides in the paracrine control of the hypothalamo-pituitary-adrenal axis. Int Rev Cytol 206: 249-284, 2001. 
27. Spinazzi R, Andreis PG and Nussdorfer GG: Neuropeptide-Y and Y-receptors in the autocrine-paracrine regulation of adrenal gland under physiological and pathophysiological conditions (Review). Int J Mol Med 15: 3-13, 2005.

28. Conconi MT, Spinazzi R and Nussdorfer GG: The endogenous ligands of PACAP/VIP receptors in the autocrine-paracrine regulation of the adrenal gland. Int Rev Cytol 249: 1-51, 2006.

29. Mazzocchi G, Andreis PG, De Caro R, Aragona F, Gottardo L and Nussdorfer GG: Cerebellin enhances in vitro secretory activity of human adrenal gland. J Clin Endocrinol Metab 84: 632-635, 1999 .
30. Albertin G, Malendowicz LK, Macchi C, Markowska A and Nussdorfer GG: Cerebellin stimulates the secretory activity of the rat adrenal gland: in vitro and in vivo studies. Neuropeptides 34: 7-11, 2000.

31. Raha D, Tortorella C, Neri G, Prasad A, Raza B, Raskar R, Dubey R, Sen NS, Macchi C, Malendowicz LK, Ahmad MF and Nussdorfer GG: Atrial natriuretic peptide enhances cortisol secretion from guinea-pig adrenal gland: Evidence for an indirect paracrine mechanism probably involving the local release of medullary catecholamines. Int J Mol Med 17: 633-636, 2006. 